\title{
Construction of 3D Rainfall Threshold Surface for Debris Flow Warning
}

\author{
Chien-Yuan Chen and Ho-Wen Chen
}

\begin{abstract}
Rainfall-induced debris flow caused by climate change has recently become a threat to human life worldwide. Types of rainfall characteristics, namely, high rainfall intensity for a short duration, high accumulated rainfall for a long duration, and postseismic effects were investigated to build a 3D rainfall threshold surface for debris flow warning. Rainfall parameters including effective accumulated rainfall, intensity, and duration were investigated in the 3D analysis. The construction of a 3D rainfall threshold surface enhances knowledge on the rainfall characteristics that initiate debris flows. Rainfall monitoring in consideration of different rainfall characteristics can improve predictions of debris flow and thus facilitate the issue of timely warnings.
\end{abstract}

Index Terms - Debris flow, warning, 3D, rainfall threshold.

\section{INTRODUCTION}

Climate-change-triggered torrential-rainfall-induced debris flow has recently become a threat to human life worldwide. Natural disaster-induced accidents increased in 2005 as a result of the sequenced intense typhoons Haitang (July), Matsa (August), and Longwang (September) hitting Taiwan. Additionally, typhoons brought severe wind, floods, landslides, and debris flows from Bilis (July, 2006), Sepat (August, 2006), and Krosa (October, 2006), and from Kalmaegi (July, 2008), Sinlaku (September, 2008), and Jangmi (September, 2008).

Typhoon Morakot landed Taiwan on 7-10 August, 2009, bringing heavy rainfall and serious floods in southern Taiwan. The typhoon-induced disasters were attributed to its slow velocity, which led to long rainfall duration and high rainfall intensity [1]. Rainfall from Typhoon Marakot triggered numerous debris flows in southern Taiwan in 2009. Fig. 1 shows some debris flow disasters after Typhoon Morakot in southern Taiwan in 2009. In all, 398 residents were buried by a dam-breach-induced debris flow in Shaolin Village when Typhoon Morakot struck Taiwan [2]. Fig. 2 Shows debris flow blockages resulting in a stream that scoured the lower terrace of Longhua Elementary School in Nantou County [3].

Typhoon Morakot was an extreme rainfall event exceeding a 200 yr recurrence amount at many rain gauge stations causing severe floods, landslides and debris flows in southern Taiwan [4]. A high-precision real-time rainfall monitoring system for debris flow warning is urgently required for

Manuscript received May 4, 2017; revised July 12, 2017.

Chien-Yuan Chen is with the National Chiayi University, Chiayi City 60004, Taiwan (e-mail: chienyuc@mail.nacy.edu.tw).

Ho-Wen Chen is with the Department of Environmental Science and Engineering, Tunghai University, Taichung City 40704, Taiwan R.O.C. (e-mail: hwchen@thu.edu.tw). disaster prevention and mitigation in Taiwan.

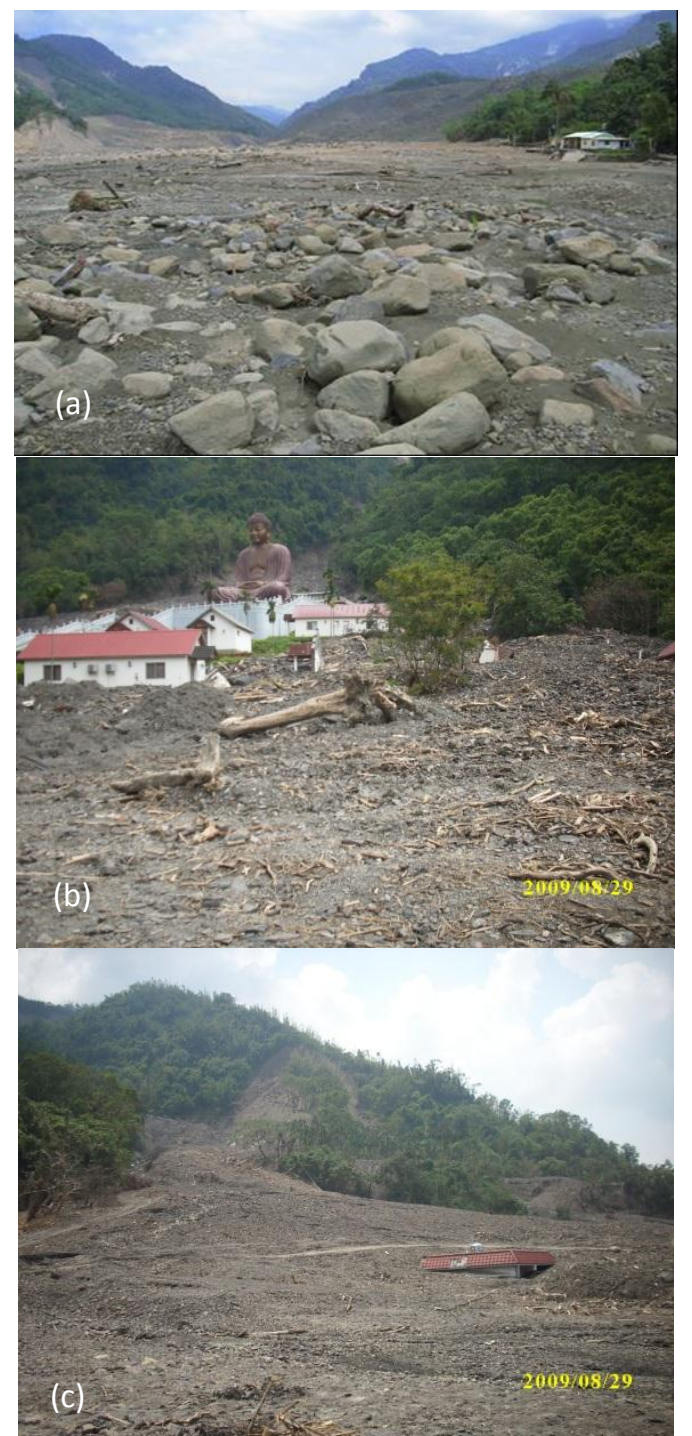

Fig. 1. Debris flow disasters after Typhoon Morakot in southern Taiwan in 2009 (a) debris masses buried Shaolin Village, (b) debris buried farm, (c) debris buried hot spring village.

Taiwan has 1705 debris-flow-prone creeks [5]. After Typhoon Herb in 1996, only 485 debris-flow-prone creeks were present. The number of debris-flow-prone creeks increased after the $\mathrm{M}_{\mathrm{L}}$ 7.3 Chi-Chi earthquake in Taiwan in 1999. Postseismic landslides resulted in up to 1420 creeks being prone to debris flow in 2001 during typhoons Toraji and Nari. Torrential rains from Typhoon Marakot abruptly increased the number of debris-flow-prone creeks to 1503. The number has been continually increasing in recent years (Fig. 3). 

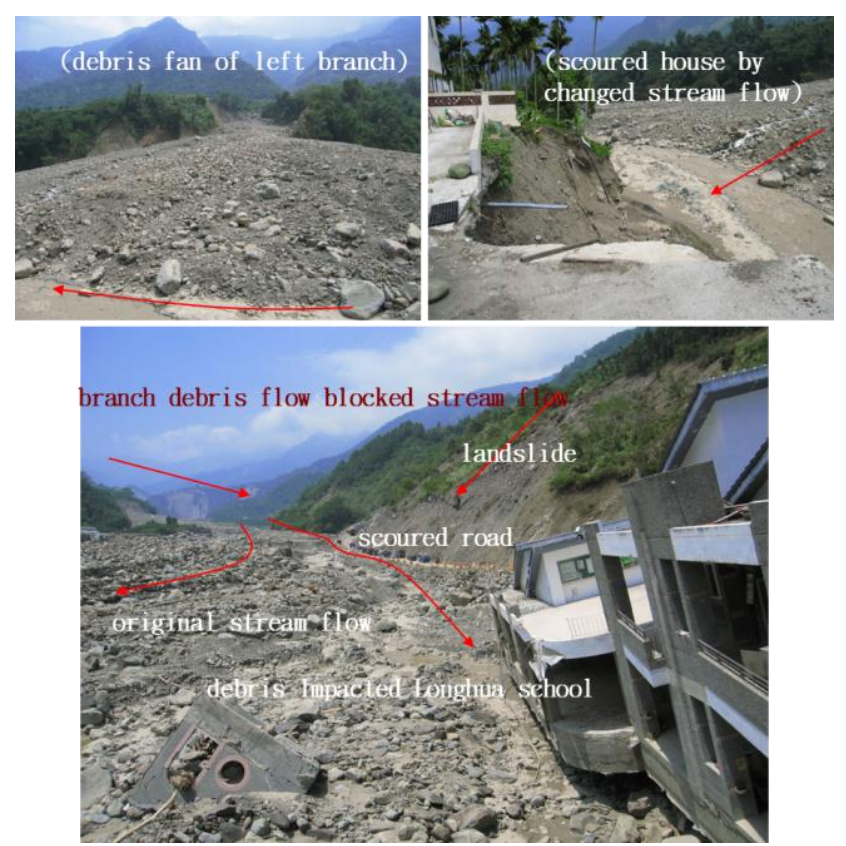

Fig. 2. Debris flow blockages resulting in a stream that scoured the lower terrace of Longhua Elementary School in Nantou County [3].

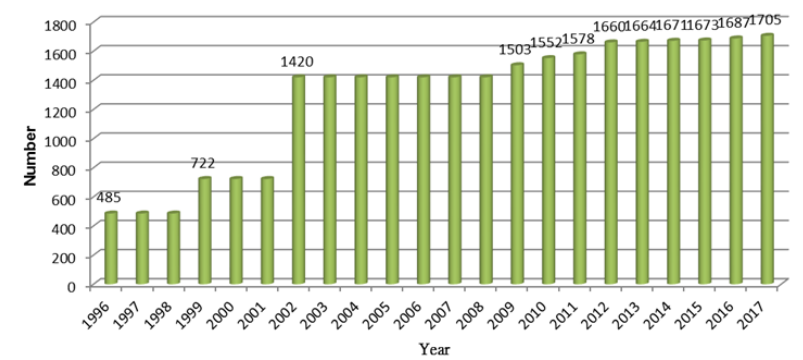

Fig. 3. Statistical analysis of the number of debris-flow-prone creeks in Taiwan.

Rainfall monitoring is the main methodology for debris flow warning. Early and precise rainfall monitoring could provide sufficient time for emergency evacuation of residents. The most commonly used rainfall parameters for debris flow monitoring include (effective) accumulated rainfall, duration, and intensity. The commonly used combinations of debris flow thresholds include accumulated rainfall-intensity [6]-[7] and intensity-duration [8]-[12]. However, no studies have used a spatial threshold surface for debris flow warning.

Table 1 lists the available rainfall threshold equations based on rainfall intensity and duration. The rainfall threshold equation for debris flow and landslide warning is expressed in the following form:

$$
\mathrm{I}=\alpha \mathrm{D}^{-\beta}
$$

where parameters $\alpha$ and $\beta$ are constant.

TABLE I: RAINFALL THRESHOLD EQUATIONS BY RAINFALL INTENSITY AND

\begin{tabular}{lll} 
& DuRATION & \\
\hline Equation & Type & Reference \\
\hline $\mathrm{I}=14.82 \mathrm{D}^{-0.39}$ & $\begin{array}{l}\text { Shallow landslide and } \\
\text { debris flow }\end{array}$ & {$[13]$} \\
\hline $\mathrm{D}=0.9 /(\mathrm{I}-0.17)$ & Debris flow & {$[14]$} \\
\hline $\mathrm{I}=30.53 \mathrm{D}^{-0.57}$ & $\begin{array}{l}\text { Debris flow and } \\
\text { landslide }\end{array}$ & {$[15]$} \\
\hline $\mathrm{I}=91.46 \mathrm{D}^{-0.82}$ & Landslide & {$[16]$} \\
\hline $\mathrm{I}=12(1 / \mathrm{D}+0.07)$ & $\begin{array}{l}\text { Soil slips and debris } \\
\text { flow }\end{array}$ & {$[17]$} \\
\hline
\end{tabular}

\begin{tabular}{lll}
\hline $\mathrm{I}=63 / \mathrm{D}+6.05$ & Debris flow & {$[18]$} \\
\hline $\mathrm{I}=12.45 \mathrm{D}^{-0.42}$ & Landslide & {$[19]$} \\
\hline $\mathrm{I}=0.82 \mathrm{D}^{-0.19}$ & Landslide & {$[20]$} \\
\hline $\mathrm{I}=73.9 \mathrm{D}^{-0.79}$ & Landslide & {$[21]$} \\
\hline $\mathrm{I}=2.2 \mathrm{D}^{-0.44}$ & $\begin{array}{l}\text { Shallow landslide and } \\
\text { debris flow }\end{array}$ & {$[22]$} \\
\hline $\mathrm{I}=6.61 \mathrm{D}^{-0.77}$ & Debris flow & {$[23]$} \\
\hline $\mathrm{I}=2.18 \mathrm{D}^{-0.26}$ & Shallow landslide & {$[24]$} \\
\hline $\mathrm{I}=25.96 \mathrm{D}^{-0.24}$ & Debris flow & {$[25]$} \\
\hline $\mathrm{I}=0.45 \mathrm{D}^{-0.09}$ & Mudflow & {$[26]$} \\
\hline $\mathrm{I}=52.86 \mathrm{D}^{-0.45}$ & Landslide, debris flow, & {$[27]$} \\
& and rock slide & \\
\hline $\mathrm{I}=2.63 \mathrm{D}^{-0.3}$ (summer) & Debris flow \\
$\mathrm{I}=3.64 \mathrm{D}^{-0.28}$ (fall) & Shallow landslide and & {$[29]$} \\
\hline $\begin{array}{l}\mathrm{I}=2.97 \mathrm{D}^{-0.41}(5 \% \\
\text { threshold) }\end{array}$ & debris flow \\
\hline $\begin{array}{l}\mathrm{I}=3.99 \mathrm{D}^{-0.65} \\
(1 \% \text { exceedance } \\
\text { probability) }\end{array}$ & Debris flow \\
\hline
\end{tabular}

\section{Study AREA AND Methodology}

Taiwan is located at the intersection of the Eurasian plate and Philippine plate. Thus, it has a fragile geological condition and is prone to frequent earthquakes. Moreover, the topography of Taiwan is characterized by mountains with an elevation of approximately $3000 \mathrm{~m}$ and short rivers (Fig. 4). Taiwan is also located on the track of typhoons and is prone to torrential rains brought by the typhoons.

Data from documented debris flows were collected to construct a 3D threshold surface for debris flow warning (Fig. $4)$. The data set comprises 61 postseismic debris flows from 1999 to 2001 [6], 11 landslides and debris flows in 2008, and 38 landslides and debris flows in 2009 [31]. The different periods of debris flows represent various debris flow triggering conditions, including postseismic effects, high rainfall intensity for a short duration, and high accumulated rainfall for a long duration. The three most commonly used rainfall parameters, effective accumulated rainfall ( $\left.\mathrm{A}_{\mathrm{c}-\mathrm{eff}}\right)$, rainfall duration $(\mathrm{D})$, and average rainfall intensity $\left(\mathrm{I}_{\mathrm{avg}}\right)$, were used for constructing the 3D rainfall threshold surface. Statistical computations for constructing the surface were performed using $\mathrm{R}$ [32].

The effective accumulated rainfall $\left(A_{c-e f f}\right)$ is defined as follows [31]:

$$
\underline{A}_{c \text {-eff }}=\alpha_{1} d_{1}+\alpha_{2} d_{2}+\ldots+\alpha_{14} d_{14}=\sum_{t=1}^{14} \alpha_{t} d_{t}, \alpha_{t}=0.5^{t / T}
$$

where $\alpha_{t}$ is the empirical attenuation coefficient, $d_{t}(\mathrm{~mm})$ is the daily rainfall in t days, and $\mathrm{T}$ is the half-life ( 1 day herein). The average rainfall intensity $\left(I_{\text {avg }}\right)$ is defined as follows:

$$
\mathrm{I}_{\mathrm{avg}}=\mathrm{A}_{\mathrm{c}-\mathrm{eff}} / \mathrm{D}
$$

\section{RESULTS AND DISCUSSION}

An analysis of the postseismic debris flow revealed that debris flows were initiated at a low rainfall intensity in Taiwan. The average rainfall intensity was suggested to be used for improving the monitoring efficiency [6]. The optimal regression and lower level of equations for the surface can be represented as follows (Fig. 5): 
$I_{\text {avg }}=29.11+0.034 A_{c-e f f}-0.6 \mathrm{D}\left(\mathrm{r}^{2}=56 \%\right.$, for $I_{\text {avg }}, A_{c-e f f}$, and $\mathrm{D}>0)$

$$
I_{\text {avg }}=20.26+0.02 A_{c-e f f}-0.63 \mathrm{D}(-2.5 \% \text { lower level })
$$

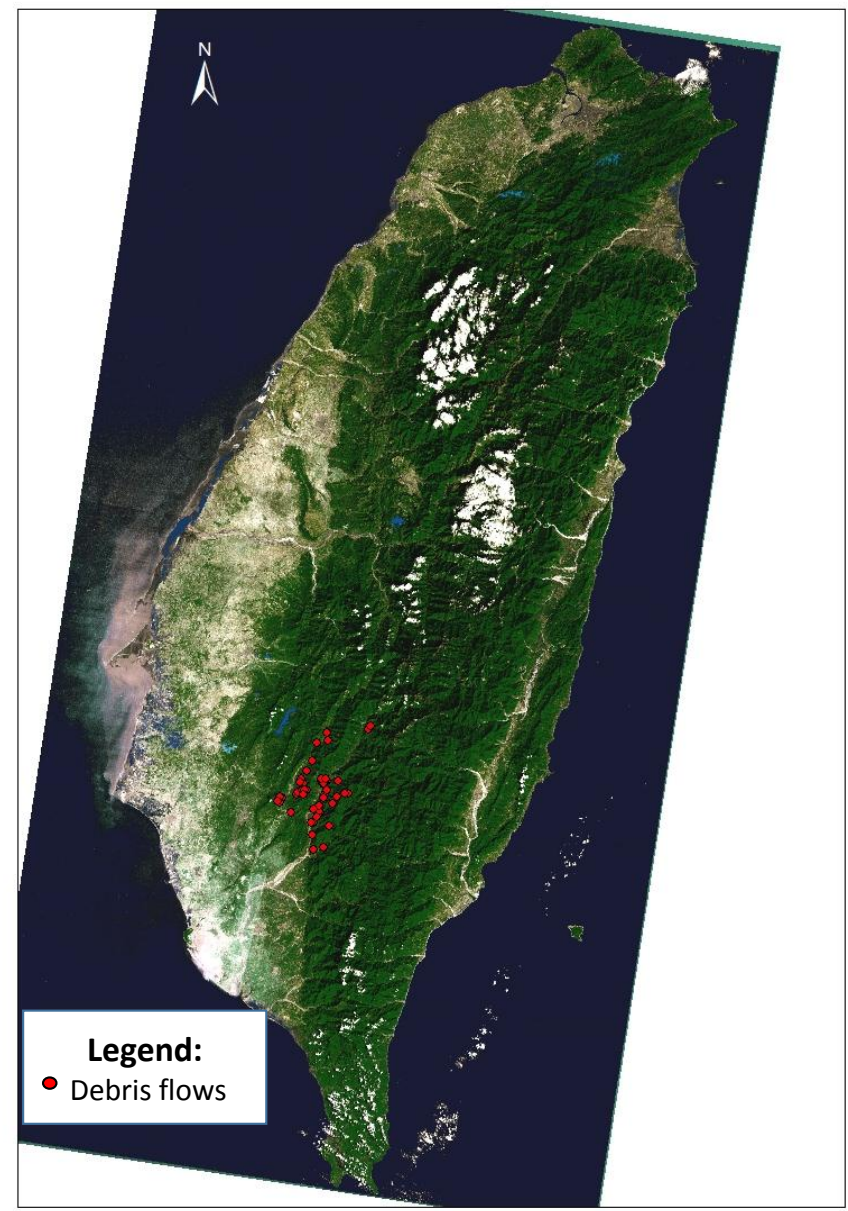

Fig. 4. Study area and site locations of initiated debris flows in 2008-2009 in Taiwan.

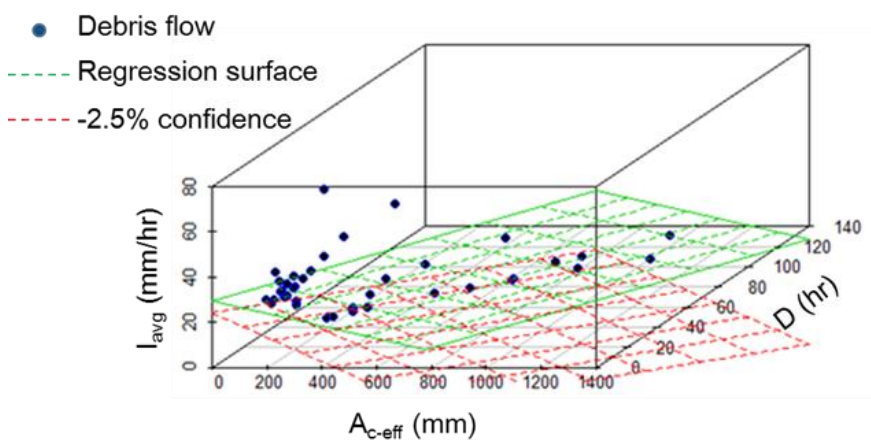

Fig. 5. 3D rainfall threshold surface for postseismic debris flows.

Debris flows were initiated by rainfall at a high intensity for a short duration during Typhoon Kalmegi in 2008. The optimal regression and lower level of equations for the surface can be represented as follows (Fig. 6):

$I_{\text {avg }}=58.35+0.098 A_{c-e f f}-5.73 \mathrm{D}\left(\mathrm{r}^{2}=97 \%\right.$, for $I_{\text {avg }}, A_{c-e f f}$, and $\mathrm{D}>0)$

$$
I_{\text {avg }}=52.27+0.08 A_{c-e f f}-6.6 \mathrm{D}(-2.5 \% \text { lower level })
$$

a long duration during Typhoon Morakot in 2009. The optimal regression and lower level of equations for the surface can be represented as follows (Fig. 7):

$$
\begin{gathered}
I_{a v g}=22.34+0.024 A_{c-e f f}-0.55 \mathrm{D}\left(\mathrm{r}^{2}=93 \%, \text { for } I_{a v g}, \mathbf{A}_{\mathrm{c}-\mathrm{eff}}\right. \text {, and } \\
\mathrm{D}>0)
\end{gathered}
$$

$$
I_{\text {avg }}=20.26+0.02 A_{c-\text { eff }}-0.63 \mathrm{D}(-2.5 \% \text { lower level })(8)
$$
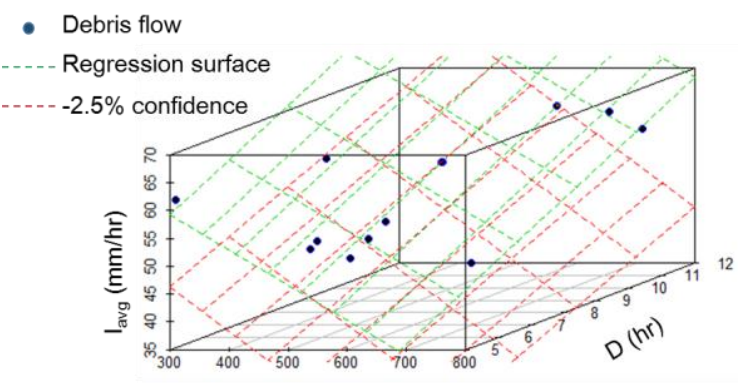

$$
A_{\text {c-eff }}(\mathrm{mm})
$$

Fig. 6. 3D rainfall threshold surface for debris flows induced by rainfall at a high rainfall for a short duration after Typhoon Kalmegi in 2008.

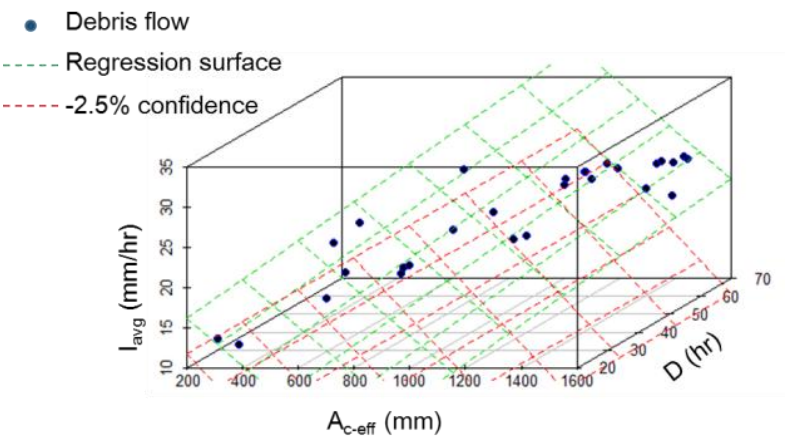

Fig. 7. 3D rainfall threshold surface for debris flows induced by high accumulated rainfall for a long duration after Typhoon Morakot in 2009.

The three events evaluated using the rainfall threshold surface exhibited notable differences (Fig. 8). The postseismic debris flows had the lowest threshold surface. Debris flows that occurred after Typhoon Morakot in 2009 exhibited a middle threshold surface under high accumulated rainfall for a long duration. Typhoon Kalmegi-induced debris flows in 2008 had the highest threshold surface under a high rainfall intensity for a short duration. The different rainfall threshold surfaces suggest that rainfall characteristics must be considered in monitoring rainfall-induced debris flows.

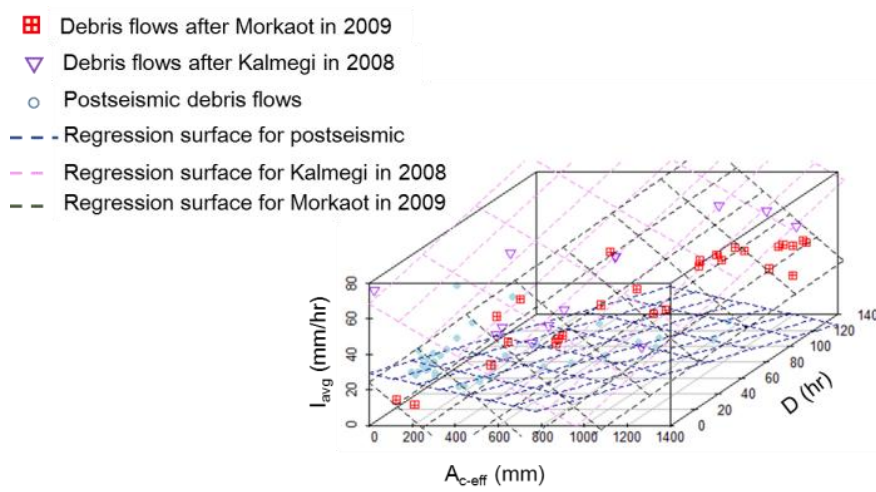

Fig. 8. Comparisons between rainfall threshold surfaces for debris flow warning.

Debris flows were initiated by high accumulated rainfall for 


\section{CONCLUSION}

Debris flow warning is an economic and effective strategy for disaster prevention and mitigation. An effective warning model can provide sufficient time for emergency evacuation. The 3D rainfall threshold surface constructed using the effective accumulated rainfall, intensity, and duration provides enhanced spatial information on the initiation of debris flows. The results obtained using various threshold surfaces reveal that various rainfall characteristics, such as high rainfall intensity for a short duration, and high accumulated rainfall for a long duration, and postseismic effects, must be considered in monitoring and issuing warnings for rainfall-induced debris flows.

\section{ACKNOWLEDGMENT}

C. Y. Chen thanks Soil and Water Conservation Bureau (SWCB), Council of Agriculture, Executive Yuan in Taiwan providing valuable data for the analysis.

\section{REFERENCES}

[1] J. D. Ben Jou, Y. C. Yu, L. Feng, Y. M. Chen, C. S. Lee, and M. D. Cheng, "Synoptic environment and rainfall characteristics of Typhoon Morakot," Atmospheric Science, vol. 38, no. 1, pp. 21-38, June 2010. (in Chinese with English abstract)

[2] C. H. Wu, S. C. Chen, and Z. Y. Feng, "Formation, failure, and consequences of the Xiaolin landslide dam, triggered by extreme rainfall from Typhoon Morakot, Taiwan," Landslides, vol. 11, pp. 357-367, June 2014.

[3] C. Y. Chen, "School infrastructure damaged investigation and climate change after Typhoon Morakot in Taiwan," International Conference on Engineering and Applied Science, July 24-27, 2012, Beijing, China.

[4] C. H. Juang, "Reconnaissance of extreme natural disasters of Morakot Typhoon, Taiwan," Engineering Geology, vol. 123, pp. 1-2, 2011.

[5] SWCB. Soil and Water Conservation Bureau in Taiwan (SWCB). Council of Agriculture, Executive Yuan. [Online]. Available: http://246.swcb.gov.tw/

[6] C. Y. Chen, T. C. Chen, F. C. Yu, W. H. Yu, and C. C. Tseng, "Rainfall duration and debris-flow initiated studies for real-time monitoring," Environmental Geology, vol. 47, pp. 715-724, March 2005.

[7] T. C. Chang and R. J. Chao, "Application of back-propagation networks in debris flow prediction," Environmental Geology, vol. 85, pp. 270-280, June 2006

[8] D. K. Keefer, R. C. Wilson, R. K. Mark, E. E. Brabb, W. M. III Brown, S. D. Ellen, E. L. Harp, G. F. Wieczorek, C. S. Alger, and R. S. Zatkin, "Real-time landslides warning during heavy rainfall," Science, vol. 238, pp. 921-925, November 1987.

[9] L. Marchi, M. Arattano, and A. M. Deganutti, "Ten years of debris flow monitoring in the Moscardo Torrent (Italian Alps)," Geomorphology, vol. 46, pp. 1-17, July 2002.

[10] G. B. Crosta and P. Frattini, "Rainfall-induced landslides and debris flows," Hydrological Processes, vol. 22, pp. 473-477, February 2008.

[10] F. Guzzetti, S. Peruccacci, M. Rossi, and C. P. Stark, "The rainfall intensity-duration control of shallow landslides and debris flows: an update," Landslides, vol. 5, pp. 3-17, February 2008.

[11] D. M. Staley, J. W. Kean, S. H. Cannon, K. M. Schmidt, and J. L. Laber, "Objective definition of rainfall intensity-duration thresholds for the initiation of post-fire debris flows in southern California," Landslides, vol. 10, pp. 547-562, October 2013.

[12] N. Caine, "The rainfall intensity-duration control of shallow landslides and debris flows," Geografiska Annaler. Series A, Physical Geography, vol. 62, pp. 23-27, 1980.

[13] G. F. Wieczorek, "Effect of rainfall intensity and duration on debris flows in central Santa Cruz Mountains," Reviews in Engineering Geology, vol. 7, pp. 93-104, 1987.

[14] R. W. Jibson, "Debris flow in southern Porto Rico," in Schultz AP, Jibson, RW (Eds.), Landslide Processes of the Eastern United States and Puerto Rico. Geological Society of America, Special Paper, vol. 236, pp. 29-55, 1989.

[15] M. C. Larsen and A. Simon, "A rainfall intensity-duration threshold for landslides in a humid-tropical environment, Puerto Rico," Geografiska Annaler, Series A, vol. 75, pp. 13-23, 1993.

[16] G. B. Crosta and P. Frattini, "Rainfall thresholds for triggering soil slips and debris flow," in Mugnai A, Guzzetti F, Roth G (Eds.), Proc. of EGS 2nd Plinius Conference 2000, Mediterranean Storms, Siena, pp. $463-488,2001$

[17] F. Fiorillo and R. C. Wilson, "Rainfall induced debris flows in pyroclastic deposits, Campania (southern Italy)," Engineering Geology, vol. 75, 263-289, November 2004.

[18] Y. Hong, R. F. Adler, and G. Huffman, "Evaluation of the potential of NASA multi-satellite precipitation analysis in global landslide hazard assessment," Geophysical Research Letter, vol. 33, L22402, November 2006.

[19] F. Guzzetti, S. Peruccacci, M. Rossi, and C. P. Stark, "Rainfall thresholds for the initiation of landslides in central and southern Europe," Meteorology and Atmospheric Physics, vol. 98, pp. 239-267, December 2007.

[20] R. K. Dahal and S. Hasegawa, "Representative rainfall thresholds for landslides in the Nepal Himalaya," Geomorphology, vol. 100, pp. 429-443, August 2008.

[21] F. Guzzetti, S. Peruccacci, M. Rossi, and C. P. Stark, "The rainfall intensity-duration control of shallow landslides and debris flows: an update," Landslides, vol. 5, pp. 3-17, February 2008.

[22] J. A. Coe, D. A. Kinner, and J. W. Godt, "Initiation conditions for debris flows generated by runoff at Chalk Cliffs, central Colorado," Geomorphology, vol. 96, pp. 270-297, April 2008.

[23] H. Saito, D. Nakayama, and H. Matsuyama, "Relationship between the initiation of a shallow landslide and rainfall intensity-duration thresholds in Japan," Geomorphology, vol. 118, pp. 167-175, May 2010.

[24] C. Tang, T. W. J. van Asch, M. Chang, G. Q. Chen, X. H. Zhao, and X. C. Huang, "Catastrophic debris flows on 13 August 2010 in the Qingping area, southwestern China: The combined effects of a strong earthquake and subsequent rainstorms," Geomorphology, vol. 139-140, pp. 559-576, February 2012.

[25] H. X. Chen and J. D. Wang, "Regression analyses for the minimum intensity-duration conditions of continuous rainfall for mudflows triggering in Yan'an, northern Shaanxi (China)," Bulletin of Engineering Geology and the Environment, vol. 73, pp. 917-928, November 2014

[26] T. Ma, C. Li, Z. Lu, and Q. Bao, "Rainfall intensity-duration thresholds for the initiation of landslides in Zhejiang Province, China," Geomorphology, vol. 245, pp. 193-206, September 2015.

[27] E. I. Nikolopoulos, M. Borga, F. Marra, S. Crema, and L. Marchi, "Debris flows in the eastern Italian Alps: seasonality and atmospheric circulation patterns," Natural Hazards and Earth System Sciences, vol. 15, pp. 647-656, 2015.

[28] C. Iadanza, A. Trigila, and F. Napolitano, "Identification and characterization of rainfall events responsible for triggering of debris flows and shallow landslides," Journal of Hydrology, vol. 541, pp. 230-245, October 2016.

[29] C. Bel, F. Liébault, O. Navratil, N. Eckert, H. Bellot, F. Fontaine, and D. Laigle, "Rainfall control of debris-flow triggering in the Réal Torrent, Southern French Prealps," Geomorphology, vol. 291, pp. 17-32, August 2017.

[30] C. Y. Chen, "Landslide and debris flow initiated characteristics after typhoon Morakot in Taiwan," Landslide, vol. 13, pp. 153-164, February 2016.

[31] R. C. R Team. (2017). A language and environment for statistical computing. [Online]. Available: http://www.R-project.org

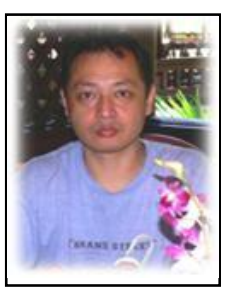

Chien-Yuan Chen was born on Oct. 27, 1969, in Changhua City, Taiwan. Ph.D. in Civil \& Environmental Engineering, University of Southern California, Los Angeles, USA, 2001. M.Sc. in Civil Engineering, National Cheng Kung University, Taiwan, 1995.

He was an associate research fellow from 2001 to 2006 at Slopeland Disaster Reduction Division, National Science and Technology Center for Disaster Reduction (NCDR), Sindian District, New Taipei City, Taiwan. He was assistant professor (2006-2009) and associate professor (2009-2013) at Department of Civil and Water Resources Engineering, National Chiayi University. He is currently as professor and Chairman at Department of Civil and Water Resources Engineering, National Chiayi University, Chiayi City, 
Taiwan since 2013. His research is focused on the following: Disaster prevention management and system, Disaster prevention education, Debris flow and landslide hazards prevention and mitigation, Geotechnical engineering, GIS application and numerical modeling.

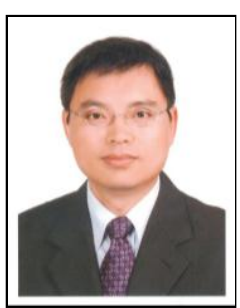

Ho-Wen Chen was born on Feb. 4, 1970, in Changhua City, Taiwan. He got the Ph.D. in National Cheng Kung Univ, Taiwan, 2000. He received his M.Sc. in environmental engineering from National Cheng Kung University, Taiwan, 1995. He was assistant professor from 2001 to 2006 and associate professor at the Department of Environmental Engineering and Management, Chaoyang University of Technology from 2006 to 2010 . He is currently as professor at Department of Environmental Science and Engineering, Tunghai University, Taichung City, Taiwan since 2010.
His research is focused on the following: sustainable system engineering, artificial intelligent and data mining, environmental informatics, water resources management, environmental forensics. 